\title{
POZYCJA UCZESTNIKA POSTĘPOWANIA SĄDOWOADMINISTRACYJNEGO W SPRAWIE STATUSU RIPOK
}

\section{POSITION OF A PARTICIPANT OF JUDICIAL REVIEW OF ADMINISTRATIVE PROCEEDING CONCERNING THE STATUS OF A REGIONAL MUNICIPAL WASTE TREATMENT PLANT}

http://dx.doi.org/10.12775/PPOS.2016.012

\section{STRESZCZENIE}

W przypadku skargi podmiotu prowadzącego działalność na rynku gospodarowania odpadami komunalnymi na uchwałę w spra-

* Magister prawa, doktorant w Katedrze Prawa Administracyjnego i Nauki o Administracji, Wydział Prawa i Administracji Uniwersytetu im. Adama Mickiewicza w Poznaniu.

*** Magister prawa, absolwent studiów doktoranckich na Wydziale Prawa i Administracji Uniwersytetu im. Adama Mickiewicza w Poznaniu. 
wie wykonania wojewódzkiego planu gospodarki odpadami szczególnie istotną kwestią jest możliwość udziału w postępowaniu sądowoadministracyjnym innych podmiotów niż organ i skarżący. Przedmiotem tych sporów jest próba zakwestionowania przez jeden z podmiotów prowadzących instalację do przetwarzania odpadów komunalnych statusu RIPOK swojego konkurenta. Z uwagi na to, że w doktrynie i orzecznictwie brak jest jednolitego stanowiska na temat tego, czy podmiot prowadzący RIPOK wpisany do uchwały wykonawczej, nie będący jednocześnie skarżącym, może przystąpić do takiego postępowania przed sądem administracyjnym w charakterze uczestnika postępowania, autorzy niniejszego opracowania starają się rozwiać występujące rozbieżności formułując tezy w tym zakresie.

\section{Słowa kluczowe}

Regionalna instalacja do przetwarzania odpadów komunalnych; uczestnik postępowania; postępowanie sądowoadministracyjne; wojewódzki plan gospodarki odpadami.

\section{ABSTRACT}

In the case of a complaint of an entrepreneur operating in the market of municipal waste management against a resolution on the implementation of a voivodship waste management plan particularly important is the possibility of participation in judicial review of administrative proceeding for persons other than the authority and an applicant. The subject of these disputes is an attempt to question by one of the entrepreneurs conducting a municipal waste treatment plant the status of a regional municipal waste treatment plant of his competitor. Due to the fact that in the doctrine and jurisprudence there is no unified position on whether the entrepreneur operating a regional municipal waste treatment plant listed in the resolution on the implementation of a voivodship waste management plan, who is not a complainant may accede to judicial review of administrative proceeding as its participant, the authors of this paper are trying to resolve existing differences by advancing theses in this area.

\section{Keywords}

Regional municipal waste treatment plant; participant of administrative proceeding; judicial review of administrative proceeding; voivodship waste management plan. 


\section{WPROWADZENIE}

W obowiązującym od dnia 1 lipca 2013 r. nowym systemie gospodarowania odpadami komunalnymi ${ }^{1}$ szczególnie istotną pozycję zajmują regionalne instalacje do przetwarzania odpadów komunalnych ${ }^{2}$. Zgodnie $\mathrm{z}$ niedawno znowelizowanym ${ }^{3}$ art. 35 ust. 6 ustawy z dnia 14 grudnia 2012 r. o odpadach ${ }^{4}$ regionalną instalacją do przetwarzania odpadów komunalnych (RIPOK) jest zakład zagospodarowania odpadów, o mocy przerobowej wystarczającej do przyjmowania i przetwarzania odpadów z obszaru zamieszkanego co najmniej przez 120 tys. mieszkańców, spełniający wymagania najlepszej dostępnej techniki, o której mowa w art. 207 ustawy z dnia 27 kwietnia 2001 r. Prawo ochrony środowiska ${ }^{5}$, lub technologii, o której mowa w art. 143 tej ustawy, w tym wykorzystujący nowe dostępne technologie przetwarzania odpadów lub zapewniający: 1) mechaniczno-biologiczne przetwarzanie zmieszanych odpadów komunalnych i wydzielanie ze zmieszanych odpadów komunalnych frakcji nadających się w całości lub w części do odzysku, lub 2) przetwarzanie selektywnie zebranych odpadów zielonych i innych bioodpadów oraz wytwarzanie z nich produktu o właściwościach nawozowych lub środków wspomagających uprawę roślin, spełniających wymagania określone w przepisach odrębnych, lub materiału po procesie kompostowania lub fermentacji

1 Wraz z wejściem w życie ustawy z dnia 1 lipca 2011 r. o zmianie ustawy o utrzymaniu czystości i porządku w gminach oraz niektórych innych ustaw (Dz. U. Nr 152, poz. 897 z późn. zm.) zapoczątkowana została głęboka reforma systemu gospodarki odpadami komunalnymi, określana niekiedy mianem „rewolucji śmieciowej”. Zmiany wprowadzone w drodze tej nowelizacji w sposób istotny zmieniły również rolę regionalnych instalacji do przetwarzania odpadów komunalnych, również na gruncie ustawy z dnia 13 września 1996 r. o utrzymaniu czystości i porządku w gminach, tekst jedn. Dz. U. z 2016 r. poz. 250 z późn. zm.; dalej: u.c.p.g.

2 Dalej jako: RIPOK.

3 Z dniem 6 lutego 2015 r., w drodze ustawy z dnia 15 stycznia 2015 r. o zmianie ustawy o odpadach oraz niektórych innych ustaw, Dz. U. poz. 122.

4 Dz. U. z 2013 r. poz. 21 z późn. zm.; dalej: u.o.

5 Tekst jedn. Dz. U. z 2016 r. poz. 672 z późn. zm. 
dopuszczonego do odzysku w procesie odzysku R10, spełniającego wymagania określone $\mathrm{w}$ przepisach wydanych na podstawie art. 30 ust. 4, lub 3) składowanie odpadów powstających w procesie mechaniczno-biologicznego przetwarzania zmieszanych odpadów komunalnych oraz pozostałości z sortowania odpadów komunalnych o pojemności pozwalającej na przyjmowanie przez okres nie krótszy niż 15 lat odpadów w ilości nie mniejszej niż powstająca w instalacji do mechaniczno-biologicznego przetwarzania zmieszanych odpadów komunalnych.

Wojewódzkie plany gospodarki odpadami ${ }^{6}$ uchwalane są na wniosek zarządu województwa przez sejmik województwa, o czym stanowi art. 36 ust. 2 u.o. Analogiczne regulacje zawierała poprzednia ustawa o odpadach (patrz: art. 14a ust. 2 ustawy z dnia 27 kwietnia 2001 r. o odpadach7), na podstawie której uchwalone zostały wszystkie obecnie obowiązujące WPGO. Jednocześnie $\mathrm{w}$ art. 38 ust. 1 u.o. (art. 15 ust. 1 starej u.o.) ustawodawca wskazał, że wraz z uchwaleniem WPGO sejmik województwa podejmuje uchwałę $\mathrm{w}$ sprawie jego wykonania (dalej: uchwała wykonawcza). To właśnie ta uchwała określa regionalne instalacje do przetwarzania odpadów (RIPOK) w poszczególnych regionach gospodarki odpadami komunalnymi oraz instalacje przewidziane do zastępczej obsługi tych regionów, w przypadku gdy znajdująca się w nich instalacja uległa awarii lub nie może przyjmować odpadów z innych przyczyn oraz do czasu uruchomienia regionalnych instalacji do przetwarzania odpadów komunalnych.

W ostatnim czasie do sądów administracyjnych coraz częściej ze strony przedsiębiorców działających na rynku gospodarowania odpadami komunalnymi trafiają sprawy ze skargi na uchwałę wykonawczą. Prowadzenie działalności gospodarczej na rynku gospodarowania odpadami komunalnymi, zwłaszcza w zakresie ich przetwarzania, przerodziło się w „walkę" przedsiębiorców prowadzących instalacje do przetwarzania odpadów komunalnych o strumień tych odpadów. Istotnym jest bowiem

6 Dalej jako: WPGO. 2/2016 ra u.o.

7 Tekst jedn. Dz. U. z 2010 r. Nr 185, poz. 1243 z późn. zm.; dalej: sta- 
to, że aby instalacja mogła być „odbiorcą” strumienia odpadów komunalnych w danym regionie gospodarki odpadami komunalnymi musi ona zostać zakwalifikowana w WPGO jako RIPOK (albo tzw. „instalacja zastępcza”). Jednocześnie im więcej jest RIPOK przypisanych do danego regionu, tym większa jest konkurencja na rynku przetwarzania odpadów komunalnych, a w konsekwencji strumień odpadów komunalnych pochodzących $\mathrm{z}$ danego regionu niejednokrotnie jest rozprowadzany pomiędzy wszystkie RIPOK z tego regionu. Tym samym wzrasta liczba sporów przed sądami administracyjnymi, w których przedmiotem jest próba zakwestionowania przez jeden z podmiotów prowadzących instalację do przetwarzania odpadów komunalnych statusu RIPOK swojego konkurenta. Stronami $\mathrm{w}$ postępowaniu sądowoadministracyjnym $\mathrm{w}$ takich sprawach są tym samym z jednej strony składający skargę przedsiębiorca (bądź inny podmiot kwestionujący legalność tej uchwały), a z drugiej strony sejmik województwa podejmujący skarżoną uchwałę wykonawczą (por. art. 32 u.p.p.s.a.) ${ }^{9}$. W związku $\mathrm{z}$ tym istotne jest rozważenie, czy podmiot prowadzący RIPOK wpisany do uchwały wykonawczej, nie będący jednocześnie skarżącym, może przystąpić do takiego postępowania przed sądem administracyjnym w charakterze uczestnika postępowania. W takim przypadku bowiem toczące się postępowanie sądowoadministracyjne dotyczy jego interesu prawnego, gdyż w przy-

8 Poza zakresem niniejszego artykułu jest analiza legitymacji skargowej podmiotu inicjującego postępowanie sądowoadministracyjne w tego typu sprawach, a w szczególności analiza, czy podmiot prowadzący działalność konkurencyjną (inną instalację do przetwarzania odpadów komunalnych, w tym RIPOK lub instalację zastępczą) posiada tę legitymację, zwłaszcza w kontekście przesłanek określonych w art. 90 ustawy o samorządzie województwa.

9 Z dniem 15 sierpnia 2015 r. na mocy ustawy z dnia 9 kwietnia 2015 r. o zmianie ustawy - Prawo o postępowaniu przed sądami administracyjnymi (Dz. U. z 2015 r., poz. 658) znowelizowano art. 25 § 1 u.p.p.s.a. dzięki czemu zdolność sądową przyznano również organom administracji publicznej - w niniejszym przypadku sejmikowi województwa. Przed tym dniem w sprawach ze skargi na uchwałę sejmiku województwa przyjmowano, że co do zasady zdolność sądowa przysługiwała województwu, jako osobie prawnej (por. uchwała NSA z dnia 13 listopada 2012 r., sygn. I OPS 3/12, CBOSA). 
padku uwzględnienia skargi prowadzona przez niego instalacja utraci status RIPOK. Co równie ważne, instalacja tracąca status RIPOK, w przypadku uwzględnienia skargi, nie uzyskuje automatycznie statusu instalacji zastępczej. Oznacza to, że do czasu przyznania jej przez sejmik województwa statusu takiej instalacji, traci ona całkowitą możliwość prowadzenia dotychczasowej działalności gospodarczej. Jednocześnie w dniu 1 lipca 2018 r. wejdzie w życie przepis art. 35 ust. 4a u.o., który został dodany w drodze ustawy z dnia 15 stycznia 2015 r. o zmianie ustawy o odpadach oraz niektórych innych ustaw. Od tego dnia instalacją zastępczą będzie mogła być wyłącznie inna instalacja mająca status RIPOK w innym regionie gospodarki odpadami komunalnymi. W konsekwencji instalacja tracąca status RIPOK na skutek wyroku sądu administracyjnego nie będzie mogła prowadzić swojej działalności aż do czasu ponownego uzyskania statusu RIPOK. Odrębnym zagadnieniem, wykraczającym poza ramy niniejszego artykułu, jest wpływ wyroku sądu administracyjnego stwierdzającego nieważność części uchwały wykonawczej w zakresie przyznania określonej instalacji statusu RIPOK na działalność podmiotów odbierających odpady komunalne i dostarczające je do tej instalacji. Należy bowiem podkreślić, iż wyrok sądu administracyjnego w tego typu przypadkach ma moc ex tunc, tj. wywołuje skutki prawne $\mathrm{z}$ mocą wsteczną, od dnia wejścia w życie kwestionowanej uchwały.

Kwestia sporna w niniejszej sprawie sprowadza się do możliwości zastosowania $\mathrm{w}$ takim przypadku art. $33 \S 2$ ustawy z dnia 30 sierpnia 2002 r. - Prawo o postępowaniu przed sądami administracyjnymi ${ }^{10}$, tj. dopuszczenia do udziału $\mathrm{w}$ postępowaniu sądowoadministracyjnym w charakterze uczestnika postępowania podmiotu prowadzącego RIPOK wpisaną do uchwały wykonawczej, nie będącego jednocześnie skarżącym. 


\section{PROWADZĄCY RIPOK JAKO UCZESTNIK POSTĘPOWANIA SĄDOWOADMINISTRACYJNEGO}

Zgodnie z art. $33 \S 2$ u.p.p.s.a. udział w charakterze uczestnika może zgłosić również osoba, która nie brała udziału w postępowaniu administracyjnym, jeżeli wynik tego postępowania dotyczy jej interesu prawnego, a także organizacja społeczna, o której mowa w art. $25 \S 4$, w sprawach innych osób, jeżeli sprawa dotyczy zakresu jej statutowej działalności. Analizując ten przepis nie należy zapominać, że jest on poprzedzony przepisem art. $33 \S 1$ u.p.p.s.a., zgodnie z którym osoba, która brała udział w postępowaniu administracyjnym, a nie wniosła skargi, jeżeli wynik postępowania sądowego dotyczy jej interesu prawnego, jest uczestnikiem tego postępowania na prawach strony ${ }^{11}$. Analiza obu przepisów prowadzi do wniosku, że ustawodawca rozróżnia dwie kategorie „uczestników postępowania na prawach strony" - pierwszą, gdy dana osoba brała udział w postępowaniu administracyjnym a nie wniosła skargi oraz drugą, gdy dana osoba w ogóle nie brała udziału w postępowaniu administracyjnym, a wynik postępowania sądowoadministracyjnego dotyczy jej interesu prawnego i w związku z tym zgłasza swój udział w tym postępowaniu w charakterze uczestnika.

W części orzeczeń sądów administracyjnych prezentowany jest pogląd, iż użyty w art. $33 \S 2$ u.p.p.s.a. termin „postępowa-

11 Jednocześnie wskazać należy, że z dniem 15 sierpnia 2015 r. na mocy wskazywanej powyżej ustawy z dnia 9 kwietnia 2015 r. o zmianie ustawy Prawo o postępowaniu przed sądami administracyjnymi (Dz. U 2015 poz. 658) dodano do art. 33 u.p.p.s.a. § 1a i § 1b. Zgodnie z pierwszym z tych przepisów, jeżeli przepis szczególny przewiduje, że strony postępowania przed organem administracji publicznej są zawiadamiane o aktach lub innych czynnościach tego organu przez obwieszczenie lub w inny sposób publicznego ogłaszania, osoba, która brała udział w postępowaniu i nie wniosła skargi, a wynik postępowania sądowego dotyczy jej interesu prawnego, jest uczestnikiem tego postępowania na prawach strony, jeżeli przed rozpoczęciem rozprawy złoży wniosek o przystąpienie do postępowania. Natomiast zgodnie z § 1b, jeżeli wynik postępowania sądowego nie dotyczy interesu prawnego osób, o których mowa w $\S 1$ i 1a, a żądają one dopuszczenia do udziału w postępowaniu, sąd wydaje na posiedzeniu niejawnym postanowienie o odmowie dopuszczenia do udziału w sprawie. Na postanowienie przysługuje zażalenie. 
nie administracyjne" należy interpretować wyłącznie w świetle art. 1 ustawy z dnia 14 czerwca 1960 r. - Kodeks postępowania administracyjnego ${ }^{12}$, albowiem dyspozycja art. $33 \S 2$ u.p.p.s.a. odnosi się tylko do postępowań sądowoadministracyjnych, które stanowią następstwo postępowań administracyjnych, do których zastosowanie mają przepisy k.p.a. ${ }^{13}$ Również na gruncie spraw związanych $\mathrm{z}$ dopuszczeniem do udziału w postępowaniu sądowoadministracyjnym $\mathrm{w}$ charakterze uczestnika postępowania podmiotu prowadzącego RIPOK wpisanej do uchwały wykonawczej, nie będącego jednocześnie skarżącym, zapadają orzeczenia w których prezentowane jest wąskie ujęcie pojęcia „postępowania administracyjnego”. I tak, w postanowieniu Naczelnego Sądu Administracyjnego z dnia 29 stycznia 2015 r. ${ }^{14}$, Sąd opowiedział się za niedopuszczalnością udziału w postępowaniu sądowym ze skargi na uchwałę sejmiku województwa w przedmiocie wykonania wojewódzkiego planu gospodarki odpadami podmiotu prowadzącego RIPOK wpisaną do uchwały wykonawczej, nie będącego jednocześnie skarżącym, uzasadniając to tym, że podjęcie takiej uchwały nie zostało poprzedzone postępowaniem administracyjnym w rozumieniu art. 1 k.p.a. Takie rozumowanie analizowanego przepisu powoduje, że przy jego interpretacji pomija się inne akty i czynności, o których mowa w art. $3 \S 2$ u.p.p.s.a., a które poddane zostały kontroli sprawowanej przez sądy administracyjne na podstawie przepisów u.p.p.s.a., w tym akty prawa miejscowego do których zalicza się uchwała wykonawcza (art. 3 § 2 pkt 5 u.p.p.s.a. w zw. z art. 15 starej u.o. oraz art. 38 u.o.).

Stanowisko takie błędnie i bezpodstawnie utożsamia bowiem pojęcie „postępowania administracyjnego" z ogólnym postępowaniem administracyjnym regulowanym przepisami

12 Tekst jedn. Dz. U. z 2016 r. poz. 23 z późn. zm.; dalej: k.p.a.

13 Tak m.in. postanowienie NSA z dnia 29 stycznia 2015 r., sygn. II OZ 52/15, CBOSA; oraz zapadające na gruncie zaskarżania do sądów administracyjnych miejscowych planów zagospodarowania przestrzennego będących aktami prawa miejscowego, m.in.: postanowienie NSA z dnia 16 października 2012 r., sygn. II OZ 903/12, jak również postanowienie NSA z dnia 13 grudnia 2011 r., sygn. II OZ 1298/11, oba dostępne w CBOSA.

14 Sygn. II OZ 52/15, CBOSA. 
k.p.a., który dotyczy wyłącznie wydawania niektórych decyzji administracyjnych, nie znajdując co do zasady zastosowania w przypadku innych prawnych form działania administracji. Tymczasem w k.p.a. brak jest przepisu, który wprost lub pośrednio definiowałby pojęcie „postępowania administracyjnego". Definicje w tym zakresie formułowane są w doktrynie, przy czym nie mają one charakteru jednolitego. Słusznie wskazuje B. Adamiak, iż „w doktrynie prawa administracyjnego nie ma jednolitego stanowiska co do koncepcji postępowania administracyjnego. Wyróżnia się postępowanie administracyjne w szerokim znaczeniu i postępowanie administracyjne w wąskim znaczeniu. Takie ujmowanie koncepcji postępowania administracyjnego wiąże zarówno dawna, jak i współczesna doktryna prawa administracyjnego z cechą właściwą dla administracji publicznej wielości form działania"15. Administracja publiczna realizuje swoje zadania przy użyciu różnych form działania administracji, o czym najlepiej świadczy rozbudowany katalog form objętych zakresem kontroli sądów administracyjnych, zawarty w art. $3 \S 2$ u.p.p.s.a. Tryb postępowania organów administracji publicznej w przypadku poszczególnych prawnych form działania jest znacząco zróżnicowany, podobnie jak zróżnicowana jest szczegółowość przepisów w tym zakresie - począwszy od pełnej i szczegółowej regulacji w przypadku decyzji administracyjnych wydawanych w trybie k.p.a. oraz - o czym zdają się zapominać niektóre składy sędziowskie - w trybie ustawy z dnia 29 sierpnia 1997 r. - Ordynacja podatkowa ${ }^{16}$, a skończywszy na regulacji „cząstkowej” dotyczącej np. procedury stanowienia aktów prawa miejscowego.

Tym samym zasadnym jest przyjęcie, iż terminowi „postępowanie administracyjne", o którym mowa w art. $33 \S 2$ u.p.p.s.a. należy przypisać znaczenie szerokie, uwzględniające wielość form działania administracji. W tym kontekście „postępowaniem administracyjnym" będzie każde postępowanie organu ad-

15 B. Adamiak, Koncepcja postępowania administracyjnego, [w:] System prawa administracyjnego, t. IX, Prawo procesowe administracyjne, R. Hauser, Z. Niewiadomski, A. Wróbel (red.), Warszawa 2014, s. 1.

16 Tekst jedn. Dz. U. z 2015 r. poz. 613 z późn. zm. 
ministracji publicznej zmierzające do podjęcia jednego z aktów lub czynności poddanych kontroli sądowoadministracyjnej.

Powyższa teza znajduje wyraźne potwierdzenie w doktrynie prawa administracyjnego. Przykładowo, jak słusznie wskazuje W. Chróścielewski, do kategorii uczestników postępowania, o których mowa w art. $33 \S 2$ u.p.p.s.a. należeć będzie „osoba, która nie wystosowała wezwania do usunięcia naruszenia interesu prawnego lub uprawnienia, a więc nie brała udziału w szeroko rozumianym postępowaniu administracyjnym - postępowaniu przed właściwym organem administracji publicznej, a w konsekwencji nie złożyła także skargi na uchwałę lub zarządzenie organu jednostki samorządu terytorialnego, ale wynik tego postępowania dotyczy jej interesu prawnego"17.

Także zdaniem J. Drachala, J. Jagielskiego oraz M. Cherki „pojęcie postępowania administracyjnego należy interpretować szeroko jako postępowanie przed organem administracji publicznej (...), a wręcz kierować się przedmiotowym kryterium poddania danej procedury kontroli sądowoadministracyjnej"18. Podobne stanowisko zajmuje także J. P. Tarno, wskazując w analizowanym kontekście, iż „określenie »postępowanie administracyjne«, użyte tutaj w ustawie należy rozumieć szeroko, w znaczeniu »postępowanie przed organem administracji publicznej «"19. Autor ten wskazuje jednak ponadto, że warunek wzięcia udziału $\mathrm{w}$ postępowaniu administracyjnym spełniają zarówno podmioty, które uczestniczyły w tym postępowaniu

17 W. Chróścielewski, Podmioty postępowania sądowoadministracyjnego, [w:] W. Chróścielewski, J.P. Tarno, Postępowanie administracyjne i postępowanie przed sądami administracyjnymi, Warszawa 2006, s. 448. Tak też: W. Chróścielewski, Przedmiotowy i podmiotowy zakres ochrony udzielanej przez sady administracyjne, [w:] Polskie sądownictwo administracyjne, Z. Kmieciak (red.), Warszawa 2006, s. 81. Tak też: W. Chróścielewski, Strony i uczestnicy postępowania sądowoadministracyjnego, „Państwo i Prawo” 2004, Nr 9, s. 38.

18 J. Drachal, J. Jagielski, M. Cherka, Komentarz do art. 33, [w:] Prawo o postępowaniu przed sq̨dami administracyjnymi. Komentarz, R. Hauser, M. Wierzbowski (red.), Warszawa 2011, s. 186.

19 J. P. Tarno, Podmioty postępowania sq̨dowoadministracyjnego, [w:] J. P. Tarno, E. Frankiewicz, M. Sieniuć, M. Szewczyk, J. Wyporska, Sądowa kontrola administracji, Warszawa 2006, s. 113. Tak też: J. P. Tarno, Prawo o postępowaniu przed sądami administracyjnymi. Komentarz, Warszawa 2006, s. 98. 
w obu instancjach, jak i osoby, których udział był ograniczony do uczestnictwa $\mathrm{w}$ postępowaniu pierwszoinstancyjnym albo odwoławczym, co można interpretować jako rozszerzenie pojęcia „postępowania administracyjnego" wyłącznie do postępowania, w ramach którego zapadają orzeczenia w „klasycznym” postępowaniu administracyjnym, nie zaś np. w postępowaniu, którego efektem jest podjęcie aktu prawa miejscowego ${ }^{20}$. Również zdaniem M. Romańskiej „w literaturze ugruntowany jest pogląd, że określenie »postępowanie administracyjne« należy rozumieć szeroko, gdyż oznacza ono każde "postępowanie przed organem administracji publicznej «"21. Ta sama Autorka wskazała, iż art. 33 § 2 u.p.p.s.a. „będzie miał zastosowanie także wtedy, gdy uprzednio żadne postępowanie, w którym mógłby brać udział podmiot ubiegający się o przyznanie mu statutu uczestnika. Trzeba bowiem podkreślić, że w $\S 1$ art. 33 u.p.p.s.a. ustawodawca powiązał przesłanki uzyskania statusu uczestnika postępowania sądowoadministracyjnego z mocy prawa ze statusem, jaki konkretny podmiot miał w uprzednio prowadzonym postępowaniu administracyjnym. Przepis ten nie znajdzie zatem zastosowania $\mathrm{w}$ takich sytuacjach, gdy przedmiotem zaskarżenia $\mathrm{w}$ postępowaniu sądowoadministracyjnym jest akt bądź czynność podjęta poza postępowaniem administracyjnym, a przede wszystkim - przepis prawa miejscowego lub uchwała organu jednostki samorządu terytorialnego. W postępowaniach administracyjnych dotyczących tych form działania administracji status uczestnika można uzyskać wyłącznie według reguł oznaczonych w $\S 2$ art. 33 u.p.p.s.a., po wykazaniu, że wynik postępowania dotyczy interesu prawnego podmiotu, który chce w nim brać udział na prawach strony"22.

20 J. P. Tarno, Podmioty postępowania sq̨dowoadministracyjnego, [w:] J.P. Tarno, E. Frankiewicz, M. Sieniuć, M. Szewczyk, J. Wyporska, Sądowa kontrola administracji, Warszawa 2006, s. 113.

21 M. Romańska, Komentarz do art. 33, [w:] T. Woś, H. Knysiak-Molczyk, M. Romańska, Prawo o postępowaniu przed sądami administracyjnymi. Komentarz, Warszawa 2008, s. 203.

22 M. Romańska, Wspótuczestnictwo $w$ postępowaniu sądowoadministracyjnym, [w:] Postępowanie sądowoadministracyjne, T. Woś (red.), Warszawa 2004, s. 184. 
Podobnie kwestię tę ujmuje H. Knysiak-Molczyk wskazując, iż „w literaturze powszechnie przyjmuje się, iż art. 33 $\S 2$ u.p.p.s.a. ma zastosowanie również wówczas, gdy przed wszczęciem postępowania sądowoadministracyjnego nie toczyło się żadne postępowanie, w którym miałby brać udział podmiot ubiegający się o przyznanie mu statusu uczestnika, a zatem w kategorii fakultatywnych uczestników postępowania sądowoadministracyjnego mieści się także podmiot, który nie złożył wezwania do usunięcia naruszenia interesu prawnego lub uprawnienia, a w konsekwencji nie złożył skargi na uchwałę lub zarządzenie organu jednostki samorządu terytorialnego, ale wynik tego postępowania dotyczy jej interesu prawnego"23.

Stanowisko doktryny $\mathrm{w}$ powyższym zakresie podziela także M. Niezgódka-Medek wskazując, iż „W piśmiennictwie opowiedziano się za szerokim rozumieniem pojęcia »postępowanie administracyjne « użytego $\mathrm{w}$ tym przepisie [tj. art. 33 $\S 2$ u.p.p.s.a. - przyp. własny], które powinno dotyczyć wszelkich postępowań poddanych sądowej kontroli"24.

W piśmiennictwie brak jest jednak jednolitości w rozumieniu pojęcia „postępowanie administracyjne”. Jak wskazuje B. Adamiak nie można opowiedzieć się za koncepcją prawną postępowania administracyjnego $\mathrm{w}$ szerokim znaczeniu, opierającą się wyłącznie na wielości form działania administracji publicznej, bowiem pojęcie postępowania administracyjnego powinno być odnoszone wyłącznie do postępowania o jednolitym przedmiocie - autorytatywnej konkretyzacji normy materialnego prawa administracyjnego dotyczącej uprawnienia lub obowiązku administracyjnego ${ }^{25}$.

Teza odnośnie szerokiego rozumienia pojęcia „postępowania administracyjnego" na gruncie art. 33 § 2 u.p.p.s.a. znajduje także potwierdzenie w orzecznictwie sądów administracyjnych.

23 H. Knysiak-Molczyk, Skarga kasacyjna $w$ postępowaniu sądowoadministracyjnym, Warszawa 2009, s. 210.

${ }_{24}$ M. Niezgódka-Medek, Komentarz do art. 33, [w:] B. Dauter, B. Gruszczyński, A. Kabat, M. Niezgódka-Medek, Prawo o postępowaniu przed sądami administracyjnymi. Komentarz, Warszawa 2006, s. 86.

25 B. Adamiak, op. cit., s. 8. 
Przykładowo w postanowieniu z dnia 26 kwietnia 2012 roku Naczelny Sąd Administracyjny wskazał, iż „ogólne sformułowanie przepisu art. $33 \S 2$ Prawa o postępowaniu przed sądami administracyjnymi, pozwala na przyjęcie, że odnosi się on do wszystkich rodzajów spraw sądowoadministracyjnych, w których może być wniesiona skarga do sądu administracyjnego, bez względu na to, jaki przejaw działalności administracji publicznej jest przedmiotem kontroli" 26 . W orzecznictwie wprost wskazuje się, że z faktu, że ustawodawca w § 2 art. 33 u.p.p.s.a. zamieścił zastrzeżenie, iż adresatem tego przepisu jest „również osoba, która nie brała udziału w postępowaniu administracyjnym" (co faktycznie poszerza krąg podmiotów), nie można wyprowadzić wniosku, że przepis ten ma zastosowanie jedynie w sprawach, w których wcześniej przed wniesieniem skargi do sądu było przeprowadzone postępowanie administracyjne jurysdykcyjne ${ }^{27}$.

Ponadto w orzecznictwie sądów administracyjnych wskazuje się, że użycie w art. 33 § 2 u.p.p.s.a. wyrazu „również” wskazuje na możliwość dokonania wykładni rozszerzającej tego przepisu $^{28}$. Jednocześnie dokonując wykładni tego przepisu, nie można nie zauważyć dalszej części przepisu art. 33 § 2 (zdanie pierwsze), warunkującej udział osoby w charakterze uczestnika, ,jeżeli wynik tego postępowania dotyczy jej interesu prawnego", co ma w tym zakresie decydujące znaczenie, bowiem sąd administracyjny nie ma możliwości odmówić udziału takiego podmiotu - rozstrzygnięcie sądu nie ma bowiem charakteru uznaniowego.

Jednocześnie podkreślić należy, iż przyjęcie odmiennej niż prezentowana interpretacji prowadziłoby do wniosków o charakterze całkowicie sprzecznym z założeniem o spójności systemowej prawa administracyjnego oraz o racjonalności ustawodawcy. Gdyby bowiem przyjąć, iż art. $33 \S 2$ u.p.p.s.a. dotyczy spraw rozstrzyganych $\mathrm{w}$ toku administracyjnego postępowania,

26 Sygn. II OZ 338/12, CBOSA.

27 Por. postanowienie NSA z dnia 14 czerwca 2013 r., sygn. II OZ 457/13, CBOSA.

28 Ibidem. 
toczącego się na podstawie przepisów k.p.a., poza jego zakresem pozostawałyby nie tylko postępowania sądowoadministracyjne dotyczące aktów prawa miejscowego, ale również:

a) decyzji i postanowień wydawanych na podstawie Ordynacji podatkowej;

b) decyzji i postanowień wydawanych na podstawie innych przepisów określających procedurę szczególną względem k.p.a.;

c) postanowień wydanych w postępowaniu egzekucyjnym i zabezpieczającym, na które służy zażalenie, których podstawę stanowią przepisy ustawy z dnia 17 czerwca 1966 r. o postępowaniu egzekucyjnym w administra$\mathrm{cji}^{29}$;

d) innych aktów lub czynności z zakresu administracji publicznej dotyczących uprawnień lub obowiązków wynikających z przepisów prawa.

Oznaczałoby to zatem znaczące ograniczenie uprawnień procesowych uzależnione od przepisów proceduralnych, które w danej sprawie znajdują zastosowanie. Byłoby to tym samym niezależne od formy działania administracji i jej efektów. Podkreślić bowiem należy, iż te same formy działania administracji (np. indywidualne akty administracyjne) mogą być podejmowane przez organy administracyjne w toku różnych postępowań.

Mając powyższe na uwadze stwierdzić należy, że zgodnie z dominującą zarówno w orzecznictwie, jak i doktrynie tezą, iż występujące $\mathrm{w}$ art. $33 \S 2$ u.p.p.s.a. pojęcie „postępowania administracyjnego" należy interpretować w sposób możliwie szeroki, uwzględniający zakres kognicji sądów administracyjnych, nie można z jego zakresu wyłączyć postępowania w sprawie uchwalenia uchwały wykonawczej do wojewódzkiego planu gospodarki odpadami na podstawie, czy to przepisów starej u.o., czy też nowej u.o. Innymi słowy, jeżeli podmiot prowadzący RIPOK wpisaną do zaskarżonej uchwały wykonawczej wykaże, że wynik toczącego się $\mathrm{w}$ tej sprawie przed sądem administracyjnym postępowania dotyczy jego interesu prawnego (co ma charakter niesporny z uwagi na zakres praw i obowiązków 
spoczywających na podmiotach prowadzących RIPOK, a wynikających w szczególności z przepisów u.o. oraz u.c.p.g.), należy go dopuścić do udziału w charakterze uczestnika na podstawie art. $33 \S 2$ u.p.p.s.a. Odmowa dopuszczenia do udziału w postępowaniu sądowoadministracyjnym w charakterze uczestnika, w takiej sytuacji, stanowi nie tylko bezprawne ograniczenie uprawnień procesowych takiego podmiotu, ale również naruszenie konstytucyjnego prawa do sądu. W takiej sytuacji podmiot prowadzący RIPOK nie miałby jakiegokolwiek wpływu na przebieg i wynik postępowania toczącego się przed sądem administracyjnym, które bezpośrednio wpływa na jego prawa i obowiązki. W konsekwencji zostałby pozbawiony możliwości przedstawiania argumentów na swoją korzyść i prowadzenia polemiki ze stanowiskiem skarżącego. Słusznie bowiem wskazuje się w orzecznictwie sądów administracyjnych, że ograniczenie takie może mieć miejsce jedynie w przypadku, kiedy wyraźny przepis ustawowy tak stanowi ${ }^{30}$.

\section{RELACJA POMIĘDZY U.P.P.S.A. A USTAWĄ 0 SAMORZĄDZIE WOJEWÓDZTWA}

Przechodząc do relacji pomiędzy przepisami u.p.p.s.a. a ustawą o samorządzie województwa w zakresie dopuszczalności przystąpienia $\mathrm{w}$ charakterze uczestnika postępowania przed sądem administracyjnym w sprawie ze skargi na uchwałę wykonawczą, podmiotu prowadzącego RIPOK wpisaną do tej uchwały, nie będącego jednocześnie skarżącym, wskazać należy, że w części orzeczeń sądów administracyjnych jako argument odmawiający dopuszczalności zastosowania art. $33 \S 2$ u.p.p.s.a. w takiej sprawie upatruje w przepisach ustawy z dnia 5 czerwca 1998 r. o samorządzie województwa ${ }^{31}$. Co istotne, w piśmiennictwie jednoznacznie wskazuje się, że zgłoszenie na podstawie art. $33 \S 2$ u.p.p.s.a. udziału w postępowaniu sądowoadministra-

30 Ibidem.

31 Tekst jedn. Dz. U. z 2016 r. poz. 486 z późn. zm.; dalej: u.s.w. 
cyjnym w charakterze uczestnika postępowania może nastąpić na dowolnym etapie postępowania, nawet już po wydaniu wyroku przez sąd I instancji ${ }^{32}$. Zdaniem wskazanej części orzecznictwa zgłaszanie się do udziału w sprawie dotyczącej aktów prawa miejscowego organu samorządu województwa po wydaniu wyroku w sprawie, bez wyczerpania procedury wskazanej w art. 90 u.s.w. jest niedopuszczalne, stanowi bowiem obejście wymogów ustalonych w tym przepisie ${ }^{33}$. Procedura do której odwołują się sądy, zgodnie z art. 90 u.s.w. obejmuje wezwanie organu samorządu województwa, który wydał przepis będący przedmiotem zaskarżenia do usunięcia naruszenia. Wynika z tego w sposób jednoznaczny, iż z procedury tej może skorzystać wyłącznie podmiot, który kwestionuje legalność uchwały organów województwa. Podmiot ten, w przypadku nieuwzględnienia wezwania do usunięcia prawa, może wnieść skargę do sądu administracyjnego stając się stroną postępowania - skarżącym³ ${ }^{34}$.

32 Por. np.: M. Niezgódka-Medek, Komentarz do art. 33 [w:] B. Dauter, B. Gruszczyński, A. Kabat, M. Niezgódka-Medek, Prawo o postępowaniu przed sq̨dami administracyjnymi. Komentarz, Warszawa 2006, s. 86, jak również: J. Drachal, J. Jagielski, M. Cherka, Komentarz do art. 33 [w:] Prawo o postępowaniu przed sądami administracyjnymi. Komentarz, R. Hauser, M. Wierzbowski (red.), Warszawa 2011, s. 186.

33 Por. np. postanowienie NSA z dnia 29 stycznia 2015 r., sygn. II OZ 52/15 oraz poprzedzające je postanowienie WSA w Krakowie z dnia 11 września 2014 r., sygn. II SA/Kr 494/14, czy też nieprawomocne postanowienie WSA w Poznaniu z dnia 11 lutego 2015 r., sygn. IV SA/Po 1367/14, wszystkie dostępne w CBOSA.

34 Na marginesie niniejszych rozważań wskazać należy, że obecnie w Rządowym Centrum Legislacji trwają prace nad przygotowanym przez Ministra Rozwoju projektem nowelizacji k.p.a., który oprócz wielu zmian dotyczących kształtu i przebiegu postępowania administracyjnego zakłada również zmiany w przepisach samorządowych ustaw ustrojowych (a więc m.in. w przepisach u.s.w.), w zakresie procedury zaskarżania do sądu administracyjnego aktu prawa miejscowego stanowionego przez organy jednostek samorządu terytorialnego. W tym zakresie proponuje się usunięcie konieczności wezwania do usunięcia naruszenia prawa przed wniesieniem skargi do sądu administracyjnego na taki akt do sądu administracyjnego - zob.: projekt z dnia 4 lipca 2016 r. ustawy o zmianie ustawy - Kodeks postępowania administracyjnego oraz niektórych innych ustaw, dostępny na stronach internetowych Rządowego Centrum Legislacji pod adresem: http://legislacja.rcl.gov.pl/projekt/12287313 [dostęp: 01-08-2016]. 
Tymczasem uczestnik postępowania, o którym mowa $\mathrm{w}$ art. $33 \S 2$ u.p.p.s.a., zgodnie z jednolitymi poglądami doktryny, „może uczestniczyć w postępowaniu po stronie skarżącego lub strony przeciwnej [tj. organu administracji publicznej, którego akt lub czynność jest przedmiotem zaskarżenia - przyp. własny]" ${ }^{35}$. Skoro zatem podmiot prowadzący RIPOK zamierza występować po stronie organu, wykazując zgodność z prawem uchwały wykonawczej, broniąc tym samym swojego interesu prawnego, nie sposób przyjąć, iż powinien on uprzednio wezwać organ do usunięcia naruszenia prawa. Aktywność tego podmiotu $\mathrm{w}$ toku prowadzonego postępowania sądowoadministracyjnego wiąże się bowiem z uznaniem przez niego, iż zaskarżona uchwała nie narusza prawa, a tym samym wezwanie do usunięcia naruszenia prawa podobnie jak późniejsza skarga inicjująca takie postępowanie sądowoadministracyjne jest bezpodstawna ${ }^{36}$.

Podkreślić bowiem należy, iż ochrona interesu prawnego podmiotu prowadzącego RIPOK wpisaną do skarżonej uchwały wykonawczej sprowadza się do utrzymania stanu prawnego wynikającego z tej uchwały, co niewątpliwie wskazuje jednocześnie, że wynik tego postępowania może również dotyczyć jego interesu prawnego w rozumieniu art. 33 § 2 u.p.p.s.a.

Realizacja wytycznych zawartych we wskazanych powyżej orzeczeniach sądów administracyjnych nie jest zatem możliwa. Jedynym bowiem rozwiązaniem byłoby skierowanie do sejmiku województwa pisma zatytułowanego „wezwanie do usunięcia naruszenia prawa", które w swej treści nie zawierałoby żadnych zarzutów ani argumentów, zaś jego jedynym celem byłoby dopełnienie „wymogów proceduralnych”. Na brak racjonalności takiego działania wskazuje również w jednym ze swoich

35 B. Adamiak, Podmioty postępowania sq̨dowoadministracyjnego, [w:] B. Adamiak. J. Borkowski, Postępowanie administracyjne i sq̨dowoadministracyjne, Warszawa 2005, s. 384. Podobnie: M. Masternak, Strony, uczestnicy postępowania i petnomocnicy, [w:] M. Jaśkowska, M, Masternak, E. Ochendowski, Postępowanie sądowoadministracyjne, Warszawa 2004, s. 91.

36 Por. np.: postanowienie NSA z dnia 15 kwietnia 2015 r., sygn. II OZ $228 / 15$, CBOSA. 
orzeczeń Naczelny Sąd Administracyjny ${ }^{37}$. Co więcej, przyjęcie powyższej tezy wymagałoby po stronie pomiotu prowadzącego RIPOK wiedzy, iż takie wezwanie do usunięcia naruszenia prawa zostało uprzednio skierowane do organów województwa. Tymczasem informacja o takim wezwaniu jest udostępniania co najwyżej poprzez umieszczenie stosowanej informacji w porządku obrad sejmiku województwa zamieszczanej m.in. Biuletynie Informacji Publicznej organu, o ile oczywiście przyjmie się, że to sejmik (a nie zarząd województwa) udzieli odpowiedzi na to wezwanie, do czego przepisy prawa go nie obligują, a jedynie dają taką możliwość. W przypadku braku odpowiedzi organu na wezwanie do usunięcia naruszenia prawa możliwa jest bowiem sytuacja, gdy podmiot prowadzący RIPOK dowiaduje się o postępowaniu sądowoadministracyjnym dopiero po wydaniu wyroku w tej sprawie.

Jednocześnie powyższe stanowisko oznaczałoby konieczność uprzedniego skierowania do organu wezwania do usunięcia naruszenia prawa celem stworzenia sobie potencjalnej możliwości występowania w przyszłym postępowaniu sądowoadministracyjnym. Wezwanie $\mathrm{w}$ tym zakresie winno przy takim założeniu obejmować całość aktu, gdyż nie wiadomo z góry, który jego przepis zostanie w przyszłości zaskarżony do sądu administracyjnego. Jednocześnie podmiot taki musiałby stale monitować w sądzie administracyjnym, czy dana uchwała nie została zaskarżona, co w przypadku aktów prawa miejscowego może być dodatkowo utrudnione.

\section{KONSTYTUCYJNE PRAWO DO SĄDU}

Przyjęta w wyżej zaprezentowanym stanowisku części sądów administracyjnych interpretacja art. $33 \S 2$ u.p.p.s.a. pozostaje także $\mathrm{w}$ rażącej sprzeczności z konstytucyjnie gwaranto-

37 Postanowienie NSA z dnia 15 kwietnia 2015 r., sygn. II OZ 228/15, CBOSA. 
wanym prawem do sądu (art. 45 Konstytucji $\mathrm{RP}^{38}$ ) oraz zasadą demokratycznego państwa prawa (art. 2 Konstytucji RP). Konstytucja RP gwarantuje bowiem każdemu prawo do sprawiedliwego i jawnego rozpatrzenia sprawy bez nieuzasadnionej zwłoki przez właściwy, niezależny, bezstronny i niezawisły sąd. Prawo to rozumiane jest w doktrynie szeroko, zaś jego realizacja determinowana jest wolą podmiotu pragnącego uzyskać ochronę sądową ${ }^{39}$.

Zdaniem przedstawicieli doktryny jedną z form urzeczywistnienia powyższej zasady jest możliwość przystąpienia do postępowania sądowoadministracyjnego podmiotów na prawach stron. Wskazuje się bowiem, iż „wykładnia art. $33 \S 2$ zapewniająca szeroki dostęp do procesowej pozycji uczestnika postępowania, a tym samym możliwości korzystania - na podstawie art. 12 PrPostAdm - ze służących stronie uprawnień procesowych, urzeczywistnia konstytucyjne zasady demokratycznego państwa prawnego (art. 2 Konstytucji RP) i prawa do sądu (art. 45 Konstytucji RP)"40. Pogląd ten także prezentowany jest w orzecznictwie sądów administracyjnych, czego przykładem może być postanowienie Naczelnego Sądu Administracyjnego z dnia 28 listopada 2005 roku $^{41}$. Również w najnowszym orzecznictwie Naczelnego Sądu Administracyjnego wskazuje się, że dopuszczenie podmiotu prowadzącego RIPOK jako uczestnika do udziału w postępowaniu sądowoadministracyjnym ze skargi na uchwałę wykonawczą, w której uwzględniono tę instalację respektuje konstytucyjny aspekt prawa do sądu ${ }^{42}$.

Jednocześnie podkreślić należy, iż przyjęcie w przedmiotowej sprawie interpretacji uniemożliwiającej podmiotowi prowadzącemu RIPOK przystąpienia do postępowania sądowoadministracyjnego zainicjowanego skargą na uchwałę wykonawczą, do której wpisana jest RIPOK tego podmiotu, rażąco narusza powyższe zasady konstytucyjne. Oznaczałoby to bowiem, iż pod-

38 Dz. U. z 1997 r. Nr 78, poz. 483 z późn. zm.

39 Por. B. Banaszak, Konstytucja Rzeczypospolitej Polskiej. Komentarz, Warszawa 2009, s. 239.

40 J. Drachal, J. Jagielski, M. Cherka, op. cit., s. 188.

41 Sygn. II FZ 730/05, CBOSA.

42 Tak: postanowienie NSA z dnia 15 kwietnia 2015 r., sygn. II OZ 228/15, CBOSA. 
miot taki pozbawiony został możliwości obrony swoich praw wynikających z powszechnie obowiązujących przepisów prawa. Nie mógłby on bowiem dowodzić prawidłowości (legalności) podjętej uchwały wykonawczej, która bezpośrednio wpływa na jego zakres praw i obowiązków. Jednocześnie w przypadku negatywnego wyniku postępowania sądowoadministracyjnego, z uwagi na związanie organów administracji publicznej prawomocnymi wyrokami sądów administracyjnych, nie mógłby on podejmować działań zmierzających do ponownego uzyskania uprawnień w przedmiotowym zakresie - wpisu do uchwały wykonawczej. Podmiot ten nie mógłby także zaskarżyć do sądu administracyjnego ewentualnych negatywnych rozstrzygnięć organów województwa (lub ich braku) bowiem także sądy administracyjne byłyby związane wcześniejszymi orzeczeniami, które zostałyby wydane bez jego udziału.

W konsekwencji rozstrzygnięcie sytuacji prawnej takiego podmiotu w sposób ostateczny i prawomocny odbyłoby się w postępowaniu, w którym nie może on uczestniczyć i bronić swoich praw, co stanowiłoby naruszeni art. 2 Konstytucji RP gwarantującemu każdemu podmiotowi prawo do obrony w postępowaniach, które dotyczą jego praw i obowiązków.

Powyższe wskazuje na to, iż art. 33 § 2 u.p.p.s.a. należy interpretować zgodnie z Konstytucją RP i zawartymi w niej zasadami ustrojowymi. Nawet gdyby przyjąć, iż art. $33 \S 2$ u.p.p.s.a. jest wieloznaczny i pozwala na przyjęcie dwóch rozbieżnych interpretacji, wybór jednej z nich powinien odbywać się w oparciu o Konstytucję RP. W doktrynie słusznie bowiem wskazuje się, iż „nakaz wykładni w zgodzie z konstytucją może (...) służyć jako dyrektywa wyboru między konkurencyjnymi wersjami znaczeniowymi danego przepisu"43. Jednocześnie nie sposób wskazać wartości konstytucyjnych, które byłyby chronione $\mathrm{w}$ wyniku przyjęcia interpretacji odmawiającej dopuszczenia do udziału w postępowaniu sądowoadministracyjnym w charakterze uczestnika postępowania w sprawie ze skargi na uchwałę wykonawczą, do której wpisana jest RIPOK prowadzona przez ten podmiot. 


\section{PODSUMOWANIE}

Przedstawiona analiza art. $33 \S 2$ u.p.p.s.a. oraz dotyczących tego przepisu zarówno piśmiennictwa, jak i judykatury sądów administracyjnych prowadzi do wniosku, że przepis ten należy rozumieć $\mathrm{w}$ sposób szeroki, umożliwiając tym samym podmiotowi prowadzącemu RIPOK udział w charakterze uczestnika w postępowaniu sądowoadministracyjnym ze skargi na uchwałę wykonawczą w której umieszczona jest ta instalacja. Przyjęcie odmiennej tezy prowadziłoby bowiem do niczym nieuzasadnionego pozbawienia takiego podmiotu możliwości obrony swoich praw wynikających ze zaskarżonej uchwały wykonawczej, a tym samy naruszenia konstytucyjnego prawa do sądu, wynikającego z art. 45 ust. 1 Konstytucji RP.

$\mathrm{Na}$ zakończenie zasygnalizować należy, że $\mathrm{z}$ dniem 15 sierpnia 2015 r. w drodze wskazywanej już nowelizacji P.p.s.a., w art. $33 \S 2$ u.p.p.s.a. wyraźnie wskazano, że postanowienie o dopuszczeniu do udziału w postępowaniu w charakterze uczestnika postępowania sąd wydaje na posiedzeniu niejawnym. W przeszłości kwestia ta wywoływała szereg wątpliwości które skutkowały wydawaniem przez sądy administracyjne, przedmiotowych postanowień na posiedzeniach niejawnych ${ }^{44}$, co w konsekwencji skutkowało nawet nieważność całego postępowania sądowoadministracyjnego ${ }^{45}$.

\section{BIBLIOGRAFIA}

Adamiak B., Koncepcja postępowania administracyjnego, [w:] System prawa administracyjnego, t. IX, Prawo procesowe administracyjne, R. Hauser, Z. Niewiadomski, A. Wróbel (red.), Warszawa 2014.

44 Por. np.: postanowienie WSA w Poznaniu z dnia 28 stycznia 2014 r., sygn. IV SA/Po 875/13, CBOSA.

45 Por. np.: wyrok NSA z dnia 4 listopada 2014 r., sygn. II OSK 863/14, CBOSA. 
Adamiak B., Podmioty postępowania sq̨dowoadministracyjnego, [w:] B. Adamiak. J. Borkowski, Postępowanie administracyjne i sądowoadministracyjne, Warszawa 2005.

Banaszak B., Konstytucja Rzeczypospolitej Polskiej. Komentarz, Warszawa 2009.

Chróścielewski W., Podmioty postępowania sądowoadministracyjnego, [w:] W. Chróścielewski, J. P. Tarno, Postępowanie administracyjne i postępowanie przed sq̨dami administracyjnymi, Warszawa 2006.

Chróścielewski W., Przedmiotowy i podmiotowy zakres ochrony udzielanej przez sądy administracyjne, [w:] Polskie sądownictwo administracyjne, Z. Kmieciak (red.), Warszawa 2006.

Chróścielewski W., Strony i uczestnicy postępowania sądowoadministracyjnego, „Państwo i Prawo” 2004, Nr 9.

Drachal J., Jagielski J., Cherka M., Komentarz do art. 33, [w:] Prawo o postępowaniu przed sądami administracyjnymi. Komentarz, R. Hauser, M. Wierzbowski (red.), Warszawa 2011.

Knysiak-Molczyk H., Skarga kasacyjna w postępowaniu sądowoadministracyjnym, Warszawa 2009.

Masternak M., Strony, uczestnicy postępowania i petnomocnicy, [w:] M. Jaśkowska, M, Masternak, E. Ochendowski, Postępowanie sqdowoadministracyjne, Warszawa 2004.

Morawski L., Zasady wykładni prawa, Toruń 2006.

Niezgódka-Medek M., Komentarz do art. 33, [w:] B. Dauter, B. Gruszczyński, A. Kabat, M. Niezgódka-Medek, Prawo o postępowaniu przed sądami administracyjnymi. Komentarz, Warszawa 2006.

Romańska M., Komentarz do art. 33 [w:] T. Woś, H. Knysiak-Molczyk, M. Romańska, Prawo o postępowaniu przed sądami administracyjnymi. Komentarz, Warszawa 2008.

Romańska M., Wspótuczestnictwo w postępowaniu sq̨dowoadministracyjnym, [w:] Postępowanie sq̨dowoadministracyjne, T. Woś (red.), Warszawa 2004.

Tarno J. P., Podmioty postępowania sq̨dowoadministracyjnego, [w:] J. P. Tarno, E. Frankiewicz, M. Sieniuć, M. Szewczyk, J. Wyporska, Sąowa kontrola administracji, Warszawa 2006.

Tarno J. P., Prawo o postępowaniu przed sądami administracyjnymi. Komentarz, Warszawa 2006.

Kontakt e-mail:

mateusz.karciarz@amu.edu.pl

maciej_kielbus@wp.pl 